\title{
Salmonella mediated the hemagglutinating virus of Japan- envelope transfer suppresses tumor growth
}

\author{
Che-Hsin Lee ${ }^{1,2}$, Tomoyuki Nishikawa ${ }^{3}$, Yasufumi Kaneda ${ }^{3}$ \\ ${ }^{1}$ Department of Biological Sciences, National Sun Yat-sen University, Kaohsiung, Taiwan \\ ${ }^{2}$ Department of Medical Research, China Medical University Hospital, China Medical University, Taichung, Taiwan \\ ${ }^{3}$ Division of Gene Therapy Science, Graduate School of Medicine, Osaka University, Osaka, Japan \\ Correspondence to: Che-Hsin Lee, email: chlee@mail.nsysu.edu.tw \\ Yasufumi Kaneda, email: kaneday@gts.med.osaka-u.ac.jp
}

Keywords: Salmonella, targeted therapy, polymer, hemagglutinating virus of Japan-envelope

Received: December 08, $2016 \quad$ Accepted: March 30, $2017 \quad$ Published: April 11, 2017

Copyright: Lee et al. This is an open-access article distributed under the terms of the Creative Commons Attribution License (CC-BY), which permits unrestricted use, distribution, and reproduction in any medium, provided the original author and source are credited.

\section{ABSTRACT}

Salmonella can target to tumor microenvironments after systemic treatment. The hemagglutinating virus of Japan-envelope (HVJ-E) induced apoptosis in tumor cells without toxicity in normal cells. Current HVJ-E therapeutic strategies, aimed at using HVJ-E for intratumor treatment, have shown great promise in animal models but have achieved only limited systemic treatment. The purpose of this study was to investigate the modulation of the anti-tumor efficiency of HVJ-E by coating the particles with poly (allylamine hydrochloride) (PAH), designated as P-HVJ-E. Treatment with P-HVJ-E resulted in decreased hemagglutinating activity and maintained tumor cellselective apoptosis and anti-tumor immunity. The use of Salmonella as a coating for P-HVJ-E (PHS) enhanced the antitumor activity and maintained the tumor-targeting activity. Treatment with PHS resulted in delayed tumor growth in tumor-bearing mice. Furthermore, a Western blot assay of the tumors revealed that HVJ-E targeted to the tumor after systemic treatment with PHS. These results indicate that Salmonella coating viral particles may provide a new approach for tumor therapy.

\section{INTRODUCTION}

Currently, tumor treatment suffers from a lack of specific tumor targeting agents [1]. The non-pathogenic facultative anaerobic bacteria, Salmonella, have been found to specifically target to tumor sites [2-6]. Salmonella are able to colonize small metastatic and larger tumors, because they can grow under aerobic and anaerobic conditions [7-10]. Salmonella are already widely used in a broad range of human and mouse tumors [11-19]. Over the decades, variants of tumor proteins and pathways inhibited by Salmonella have been intensively studied [20], such as indoleamine 2, 3-dioxygenase 1 (IDO-1), leading to immune tolerance [21]. Based on the observation of hypoxic regions in the tumor, Salmonella could specifically target tumor tissue [22]. Salmonella have been demonstrated as potential tumortargeting vectors for therapeutic agent delivery [23]. The advancement of cancer research may rely on a rapid shift in the engineering of oncolytic viral systems because this method has shown high efficiency and less side effects for tumor therapy, especially the hemagglutinating virus of Japan-envelope (HVJ-E) [24, 25].

Previously, the masking of Salmonella with a polymer reduced the antigenicity of Salmonella [26]. Herein, we attempted to encapsulate the hemagglutinating virus of Japan-envelope (HVJ-E) into poly (allylamine hydrochloride) (PAH) and change the surface charged of HVJ-E [26]. Polymers shield HVJ-E from the hemagglutination activity after systemic administration [26]. The presence of lipopolysaccharide (LPS) in the cell wall of gram-negative bacteria results in the negatives surface charged of Salmonella. The negatively charged bacterial surfaces can absorb the positively charged polyelectrolytes to form a complex [26]. Here, this study demonstrates that the oncolytic virus delivery into the tumor site by using tumor-targeting Salmonella to enhance the therapeutic index. 


\section{RESULTS}

\section{The encapsulation of HVJ-E into polyelectrolyte shells}

The hemagglutinin-neuraminidase $(\mathrm{HN})$ protein induced the hemmagglutination after HVJ-E systemic delivery [27-29]. To avoid the hemmagglutination, HVJ-E particles could be packaged into polyelectrolyte shells due to the negative charged of the viral envelope [30]. The HVJ-E-coated Salmonella we developed is expected to fulfill the two requirements in systemic HVJ-E delivery and enhance the Salmonella antitumor response (Figure 1). Therefore, the positively charged PAH attached to the surfaces of HVJ-E and change the charge of HVJ-E. As shown in Figure 2A, the particle sizes of PAH-modified HVJ-E (P-HVJ-E) with different PAH concentrations were measured by SEM. When compared to the size of unmodified HVJ-E, SEM analysis showed that the size of the P-HVJ-E was significantly increased. The PAH was labeled with FITC (FA-PAH) to demonstrate that PAH masked to the surface of HVJ-E. The HVJ-E was labeled with PKH26 (red). As illustrated in Figure 2B, the HVJ-E was masked with FA-PHA (Figure 2B). The gradual increase in particle size with the concentration of $\mathrm{PAH}$ of HVJ-E was evidence that HVJ-E was coated with PAH.

\section{The characterization of P-HVJ-E}

We used a hemagglutinating assay (HA) to measure the HVJ-E particles and HVJ-E masked with PAH (P-HVJ-E). The hemagglutinating activity inhibits the systemic HVJ-E treatment. When HVJ-E was added to chicken erythrocytes, hemagglutination was induced
(Hemagglutinating unit (HAU) 10240/ml) (Figure 3A). However, the hemagglutination activity was significantly decreased in P-HVJ-E group (Figure 3A). Mouse melanoma (B16F10), human prostate cancer cell cells (PC3), mouse bone marrow derived dendritic cell and human normal prostatic epithelial cells (PNT2) were treated with P-HVJ-E and HVJ-E. The proliferation of B16F10 and PC3 was inhibited, and the proliferation of mouse bone marrow-derived dendritic cells and PNT2 cells were not affected, suggesting that P-HVJ-Emediated cell death is specifically induced in tumor cells (Figure 3B-3E). HVJ-E specifically induced the apoptosis in tumor cells [24]. B16F10 cells treated with P-HVJ-E exhibited apoptosis phenotypes and the expressions of cleaved caspase-9, caspase- 3 and PARP were increased (Figure 4A). HVJ-E coated with PAH $(0.25 \mu \mathrm{g} / \mathrm{ml} \sim 0.5 \mu \mathrm{g} /$ $\mathrm{ml}$ ) maintained the antitumor activity. Suzuki et al. demonstrated that HVJ-E stimulated dendritic cells to release interleukin-6 (IL-6) [31] and that IL-6 inhibited the proliferation of regulatory T cell [32]. As shown in Figure 4B, mouse bone marrow-derived dendritic cells secreted IL-6 after the P-HVJ-E treatments. Furthermore, HVJ-E can be used for gene transfer vector in vitro and in vivo [30]. The luciferase expression was detected to explore the gene transfer activity of P-HVJ-E carrying a luciferase gene (Figure 4C). B16F10 cells treated with P-HVJ-E prepared with $1-2 \mu \mathrm{g} / \mathrm{ml}$ PAH displayed lower luciferase signals than the P-HVJ-E prepared with $0-0.5 \mu \mathrm{g} / \mathrm{ml}$ PAH. However, the expression of luciferase in P-HVJ-E prepared with $0.5 \mu \mathrm{g} / \mathrm{ml}$ PAH was detected. Therefore, HVJ-E prepared with $1-2 \mu \mathrm{g} / \mathrm{ml}$ PAH slightly decreased antitumor ability, and HVJ-E prepared with $0.25 \mu \mathrm{g} / \mathrm{ml}$ PAH still resulted in the hemagglutination. The P-HVJ-E prepared with $0.5 \mu \mathrm{g} / \mathrm{ml}$ $\mathrm{PAH}$ was used in the subsequent experiments.
A

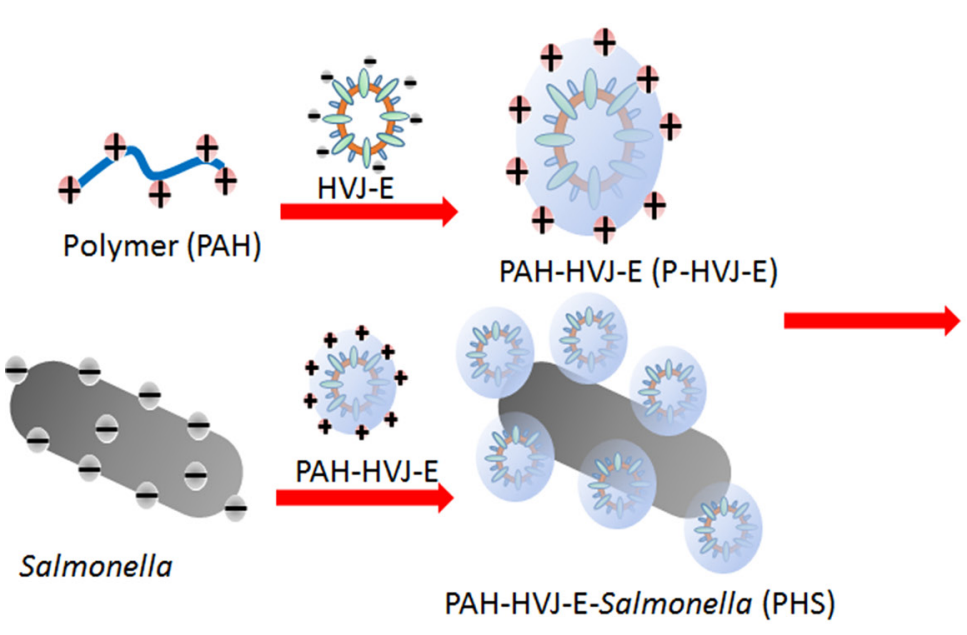

B

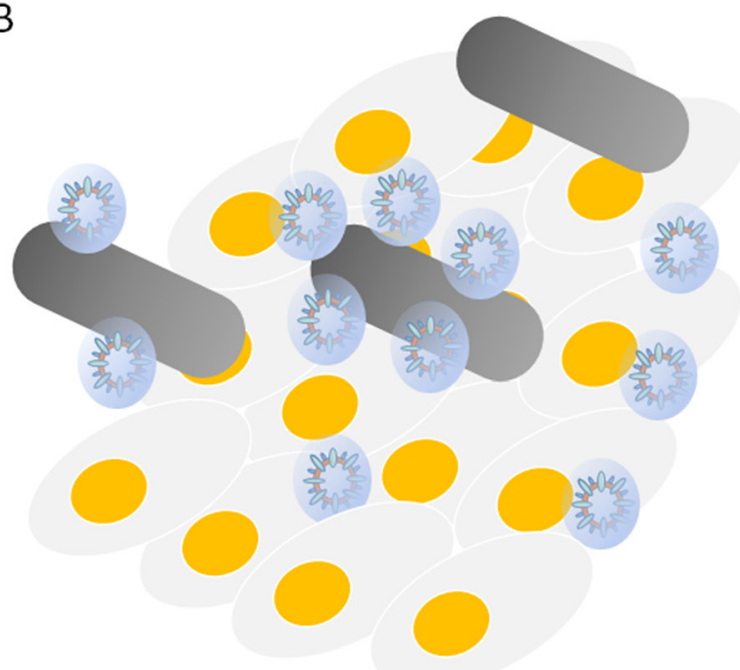

Tumor- targeting therapy

Figure 1: Schematic illustration of the HVJ-E-coated Salmonella for improved tumor targeting activity (A) Engineering of the HVJ-E-coated Salmonella. (B) Tumor-targeting delivery of the HVJ-E mediated by PAH-HVJ-E-Salmonella (PHS). 


\section{The characterization of the P-HVJ-E-masked Salmonella (PHS)}

The positively charged polyelectrolyte PAH can spontaneously attach on the cell wall of Salmonella [25]. Because the F protein of HVJ-E has membranefusing potential, HVJ-E used $\mathrm{F}$ protein as a cell-fusing or detective agent. To evaluate the number of P-HVJ-E absorbed onto the surface of Salmonella, we collected the cell pellet and supernatant at varying numbers in the presence of Salmonella followed by the Western blot assay to determine the fusion (F) protein of HVJ-E (Figure 5A).
Because one hemagglutination units (HAU) of HVJ-E corresponds to $1 \times 10^{7}$ viral particles [31], one Salmonella can absorb 50-100 P-HVJ-E particles. Furthermore, the replication activity of PHS and Salmonella were measured to determine whether the P-HVJ-E masking Salmonella affected the physiology of Salmonella. Meanwhile, the growth curve of Salmonella coated with P-HVJ-E (PHS) was not significant difference between Salmonella group (Figure 5B). The gentamicin protection/ bacterial invasion assay was used to measure the infection efficiency of PHS cells. As shown in Figure 5C, the invasion efficiency of PHS did not decrease compare with Salmonella group

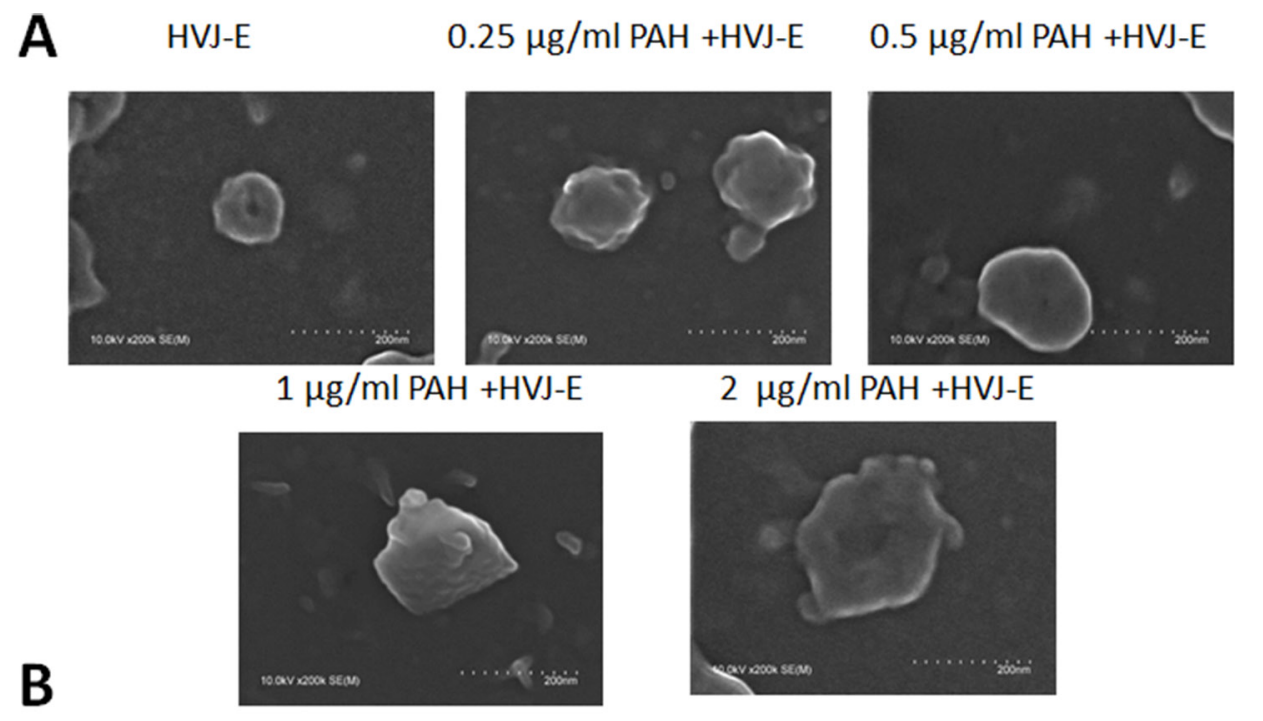

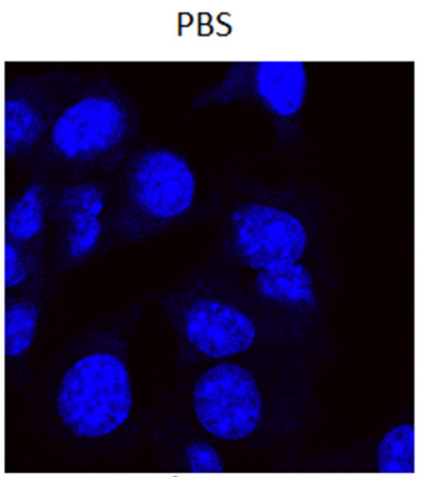

$0.5 \mu \mathrm{g} / \mathrm{ml}$ PAH $+\mathrm{HVJ}-\mathrm{E}$
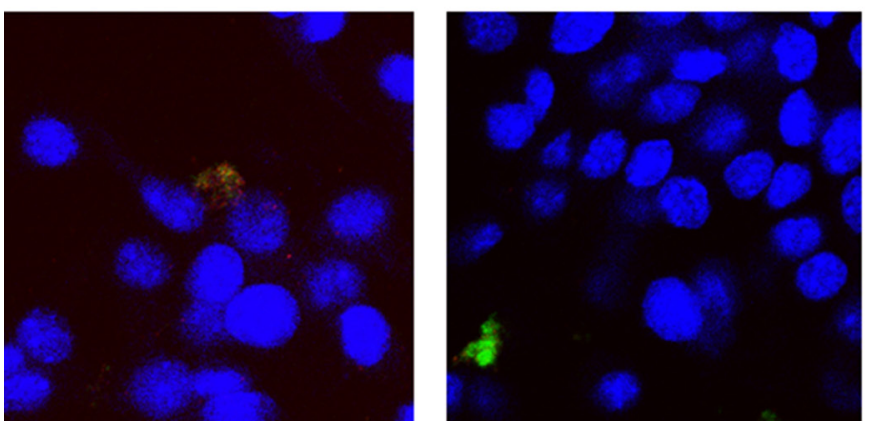

$0.25 \mu \mathrm{g} / \mathrm{ml} \mathrm{PAH}+\mathrm{HVJ}-\mathrm{E}$

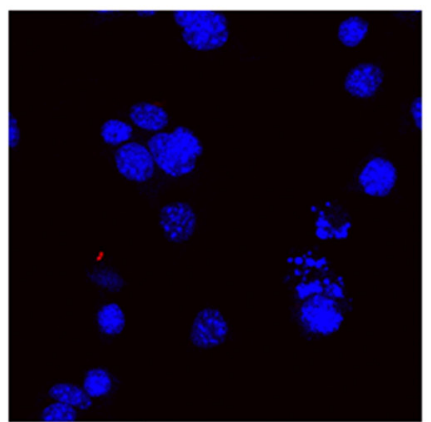

$1 \mu \mathrm{g} / \mathrm{ml} \mathrm{PAH}+\mathrm{HVJ}-\mathrm{E}$

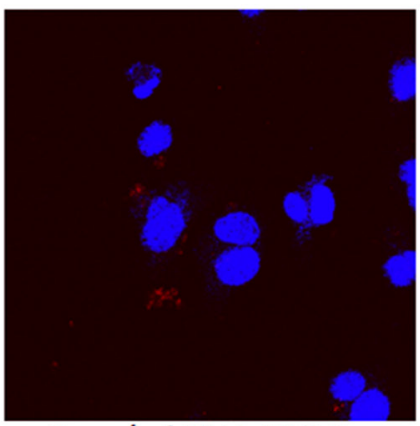

$2 \mu \mathrm{g} / \mathrm{ml}$ PAH+HVJ-E

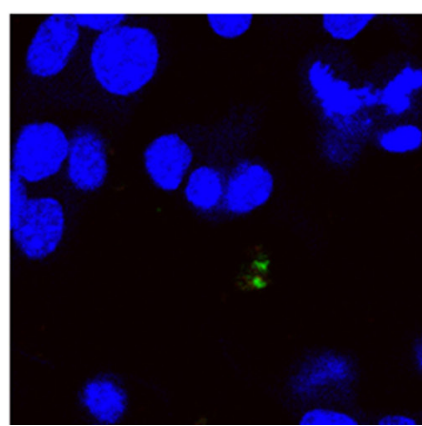

Figure 2: HVJ-E coated with PAH. (A) Electron microscopy of HVJ-E and of P-HVJ-E (PAH concentrations: $0.25-2 \mu \mathrm{g} / \mathrm{ml}$ ). Scale bar $=200 \mathrm{~nm}$ (B) B16F10 cells treated with 10 MOI of P-HVJ-E were imaged by confocal microscopy. PAH was labeled with fluorescence. HVJ-E was labeled with PKH26 (red). Cell nuclei were counterstained with DAPI. 

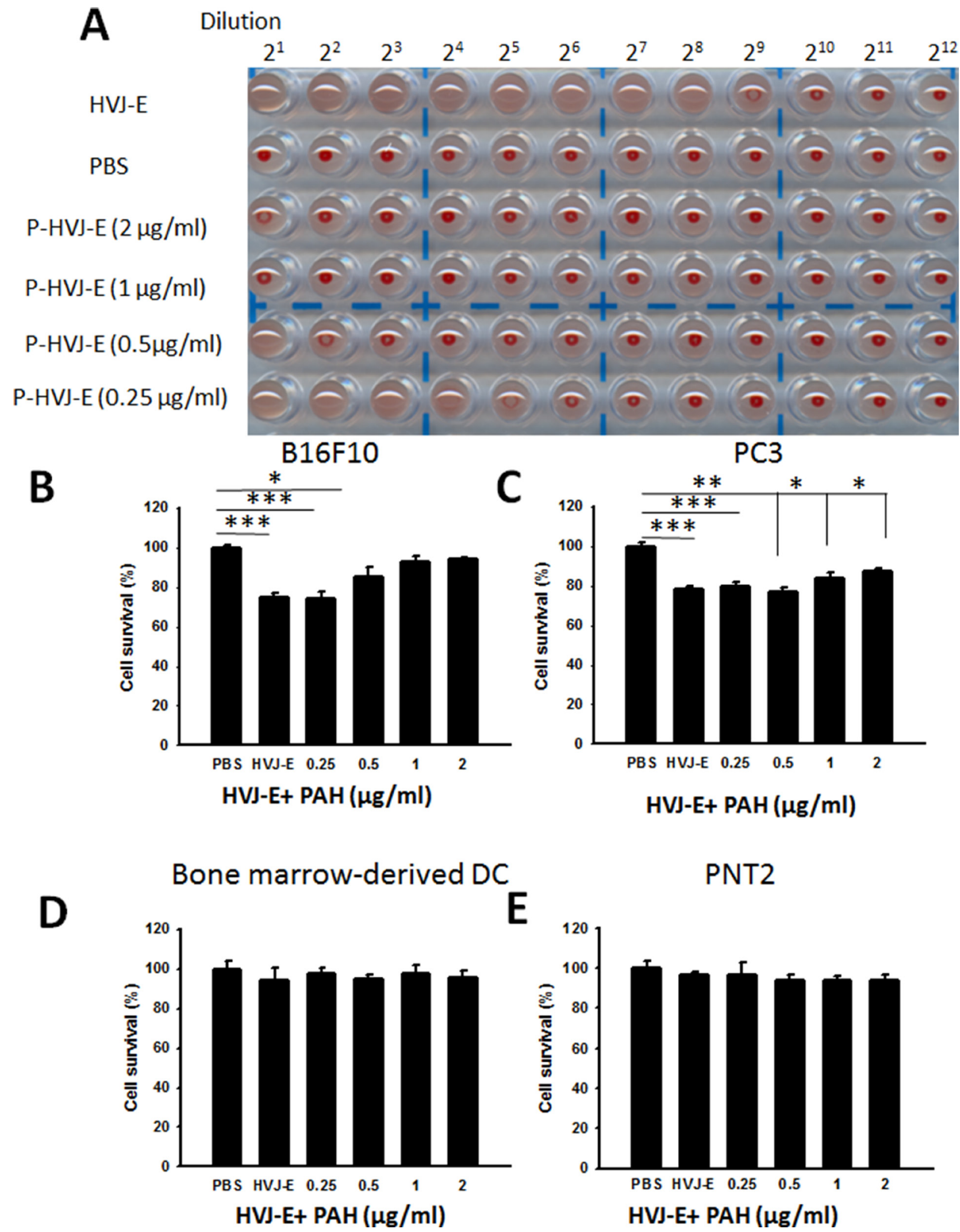

Figure 3: The characterization of P-HVJ-E. (A) The hemagglutination activity of HVJ-E coated with PAH. Two-fold dilutions of samples of PAH-coating HVJ-E $(0-2 \mu \mathrm{g} / \mathrm{ml})$ were prepared, mixed with chicken red blood cells, and added to the wells of a 96well plate. After 30 minutes, the wells were photographed. The cytotoxicity effect of PAH-coating HVJ-E. (B) B16F10 (105), (C) PC3 $\left(10^{5}\right),\left(\right.$ D) bone-marrow-derived dendritic cell $\left(10^{5}\right)$ and $(\mathbf{E})$ PNT2 $\left(10^{5}\right)$ cells were infected with HVJ-E (100 HAU) or HVJ-E coating by various concentrations PAH. The cell viability was then assessed using the WST-1 assay; the data are reported as the means \pm SD $(n=6)$. $(* P<0.05 ; * * P<0.01 ; * * * P<0.001)$ 

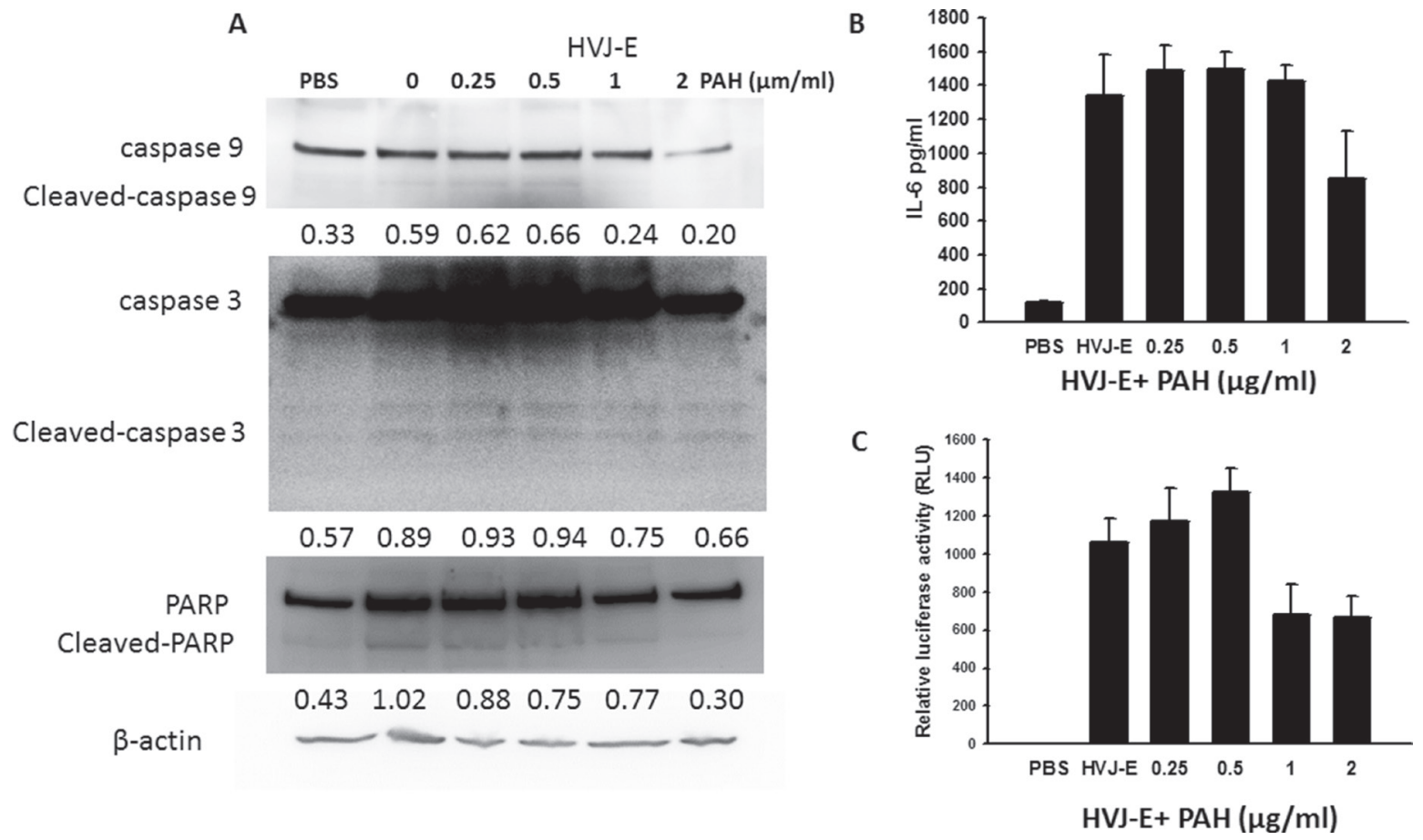

Figure 4: Activity of P-HVJ-E was similar to the activity of HVJ-E. (A) P-HVJ-E-induced cell death in B16F10 cells mediated by caspase-dependent apoptosis. After exposure to P-HVJ-E (100 HAU) for $24 \mathrm{~h}$, the expression of caspase protein in B16F10 cells was determined by immunoblot analysis. The cropped blots are displayed. The expression of $\beta$-actin served as the quantitative control. Inserted values indicated relative proteins expression in comparison with $\beta$-actin. (B) P-HVJ-E stimulated the expression of IL-6 in bone marrowderived dendritic cells. After exposure to PAH-coated HVJ-E (100 HAU) for $24 \mathrm{~h}$, the expression of IL-6 in bone marrow-derived dendritic cells was determined by ELISA. (C) Luciferase gene expression in B16F10 cells transfected with P-HVJ-E. The P-HVJ-E was incubated with B16F10 cells for $24 \mathrm{~h}$, and the luciferase activity was measured. The data are reported as the means $\pm \operatorname{SD}(n=6)$.

A
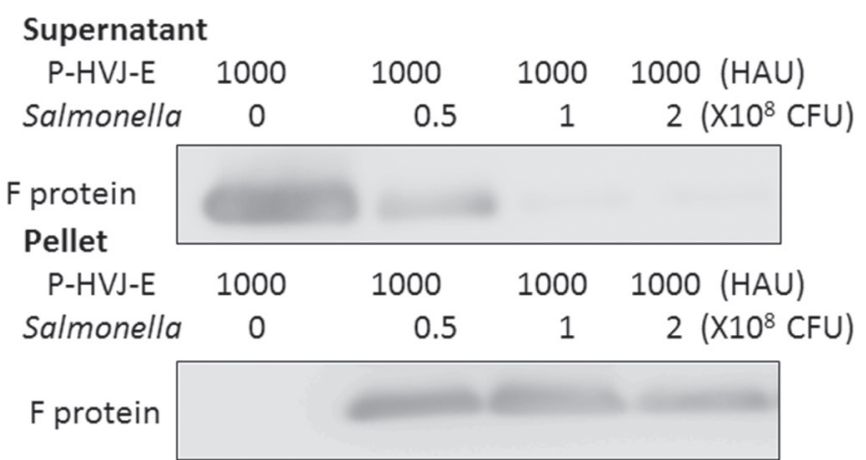

B

$\mathrm{C}$
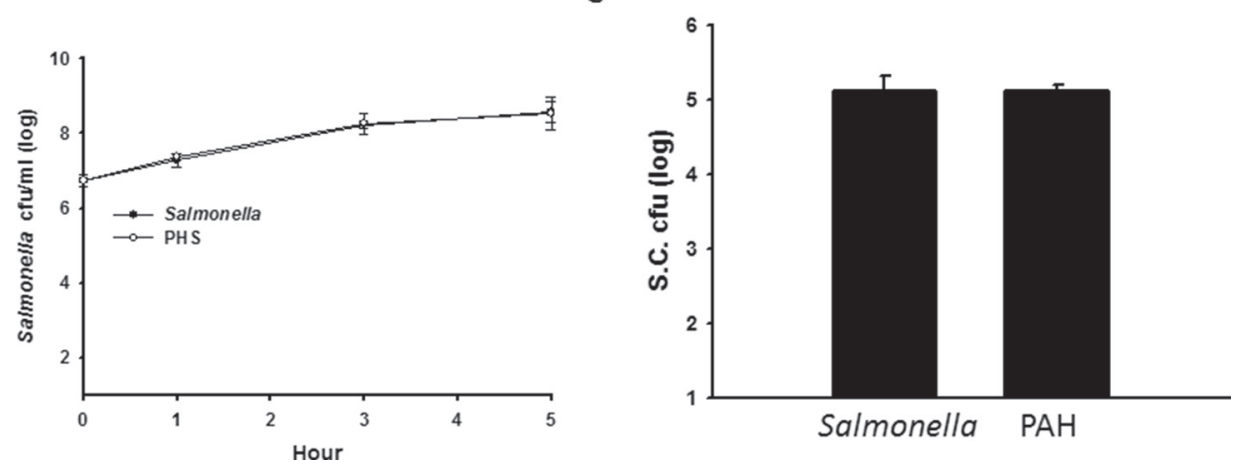

Figure 5: Salmonella coated with P-HVJ-E (PHS). (A) P-HVJ-E adhered to the Salmonella. PHS cells and supernatant were collected at different concentrations of Salmonella. The F proteins of HVJ-E from the solutions were measured using by immunoblot analysis. The cropped blots are displayed. Replication and invasion activity of PHS. (B) PHS replication. The number of Salmonella and PHS cells was determined $6 \mathrm{~h}$ post-incubation. (C) A gentamicin protection assay was used to examine these cells $9.5 \mathrm{~h}$ later; the data are reported as the means $\pm \mathrm{SD}(n=3)$. 
(Figure 5C). We used immunofluorescence assay to determine whether the P-HVJ-E particles absorbed onto the Salmonella by (Figure 6A). The P-HVJ-E particles were observed on the surface of Salmonella by using an electron microscope (Figure 6B). Next, we expected that the P-HVJ-E would be discharged from the surface of Salmonella during Salmonella replication. To determine
P-HVJ-E release in vitro, the bacterial pellets and removed supernatants were collected at several time points. The levels of P-HVJ-E decreased during Salmonella division (Figure 7A). The antitumor activity of P-HVJ-E, Salmonella and PHS against B16F10 cells was examined using a cell viability assay. The PHS significantly inhibited the cell viability of B16F10 (Figure 7B). The expression
A

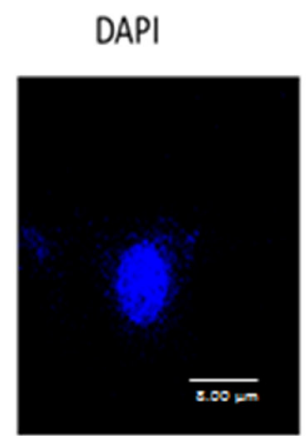

PAH-FITC-HVJ-E
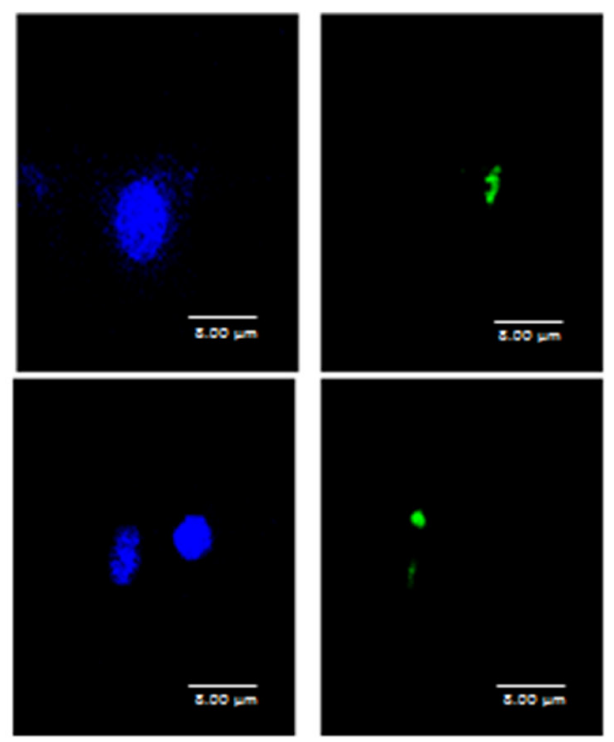

\section{Merged}
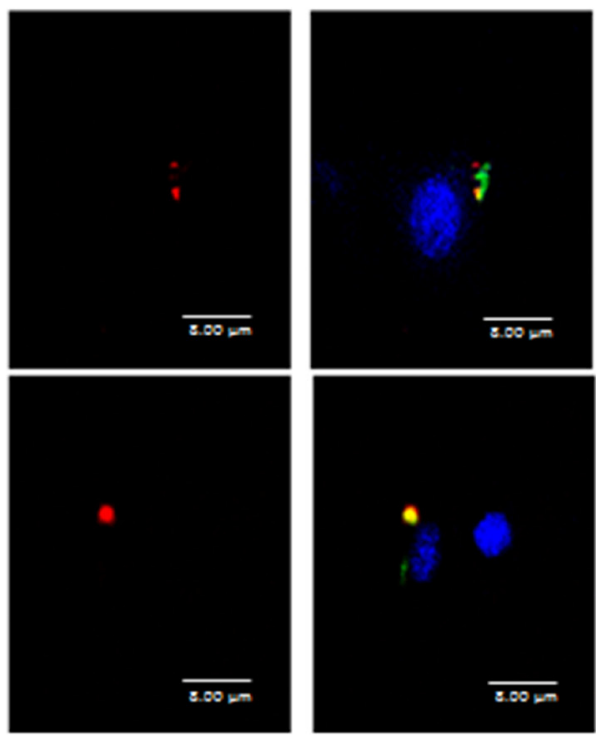

B

Salmonella

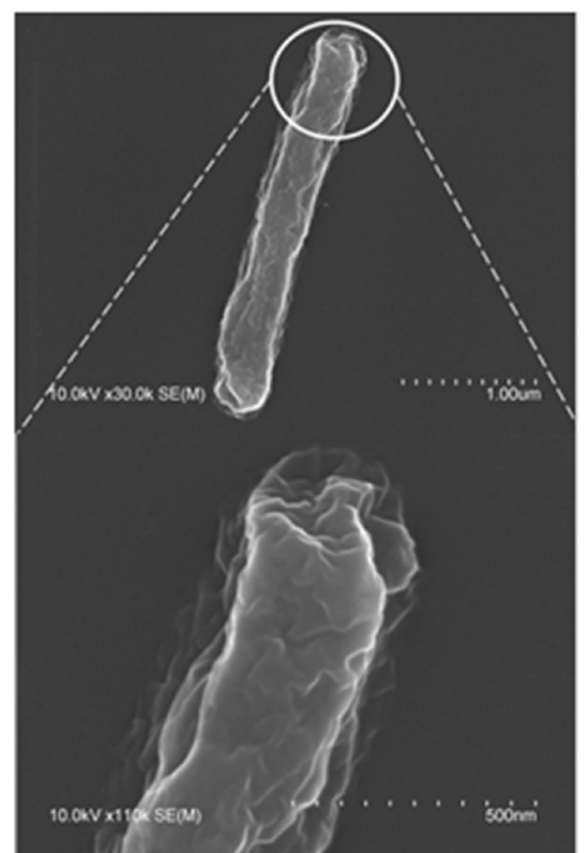

PHS

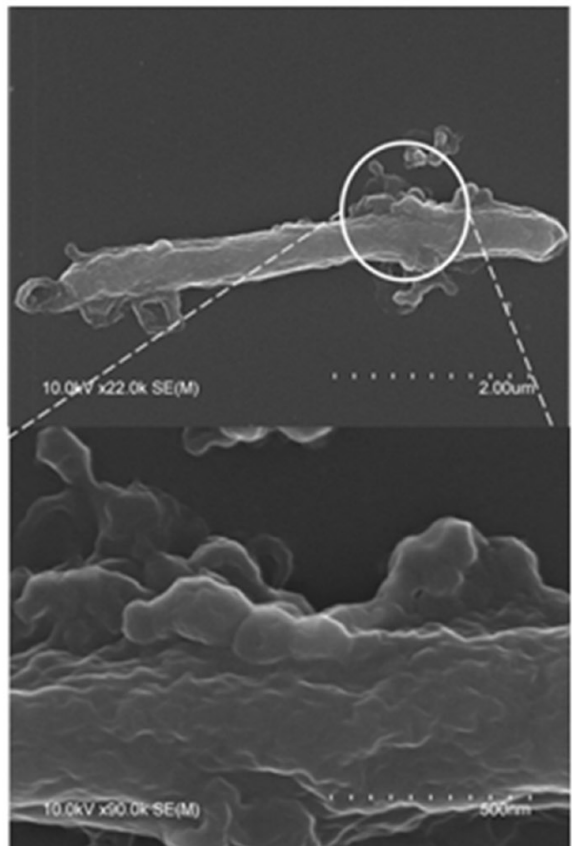

Figure 6: Salmonella coated with P-HVJ-E. (A) B16F10 cells treated with 10 MOI of PHS were imaged by confocal microscopy. PAH-HVJ-E was labeled with fluorescence. Salmonella was labeled with PKH26 (red). Cell nuclei were counterstained with DAPI. Scale bar $=8 \mu \mathrm{m}$. (B) Electron microscopy of Salmonella and of PHS. Upper: scale bar $=1 \mu \mathrm{m}-2 \mu \mathrm{m}$. Under: scale bar $=0.5 \mu \mathrm{m}$. 
of cleaved caspase 3 was also significantly observed in the PHS treatment group compared with P-HVJ-E or Salmonella groups (Figure 7C). The results suggest that P-HVJ-E could absorb onto Salmonella to form PHS and could discharged from Salmonella when Salmonella underwent replication.

\section{Tumor-targeting potential of PHS and tumor growth inhibition by PHS}

The bacteria number of PHS in B16F10 or PC3 tumor-bearing mice was measured after injection with PHS (Figure 8A, 8B). At all the time points examined, the number of Salmonella was much higher in tumors than that in the spleens and livers. The number of Salmonella in the tumors was 1,000-10,000 times more than that found in the livers or spleens. The number of Salmonella was lesser in the healthy organs compared with that in tumors in both strains of mice at day 28. Meanwhile, to examine whether Salmonella delivered P-HVJ-E to the tumor sites, we injected PHS into B16F10 or PC3 tumor-bearing mice and examined the fusion protein of HVJ-E within a tumor, liver and spleen by Western blot assay. The HVJ-E was found in the tumor sites, whereas it was slightly found

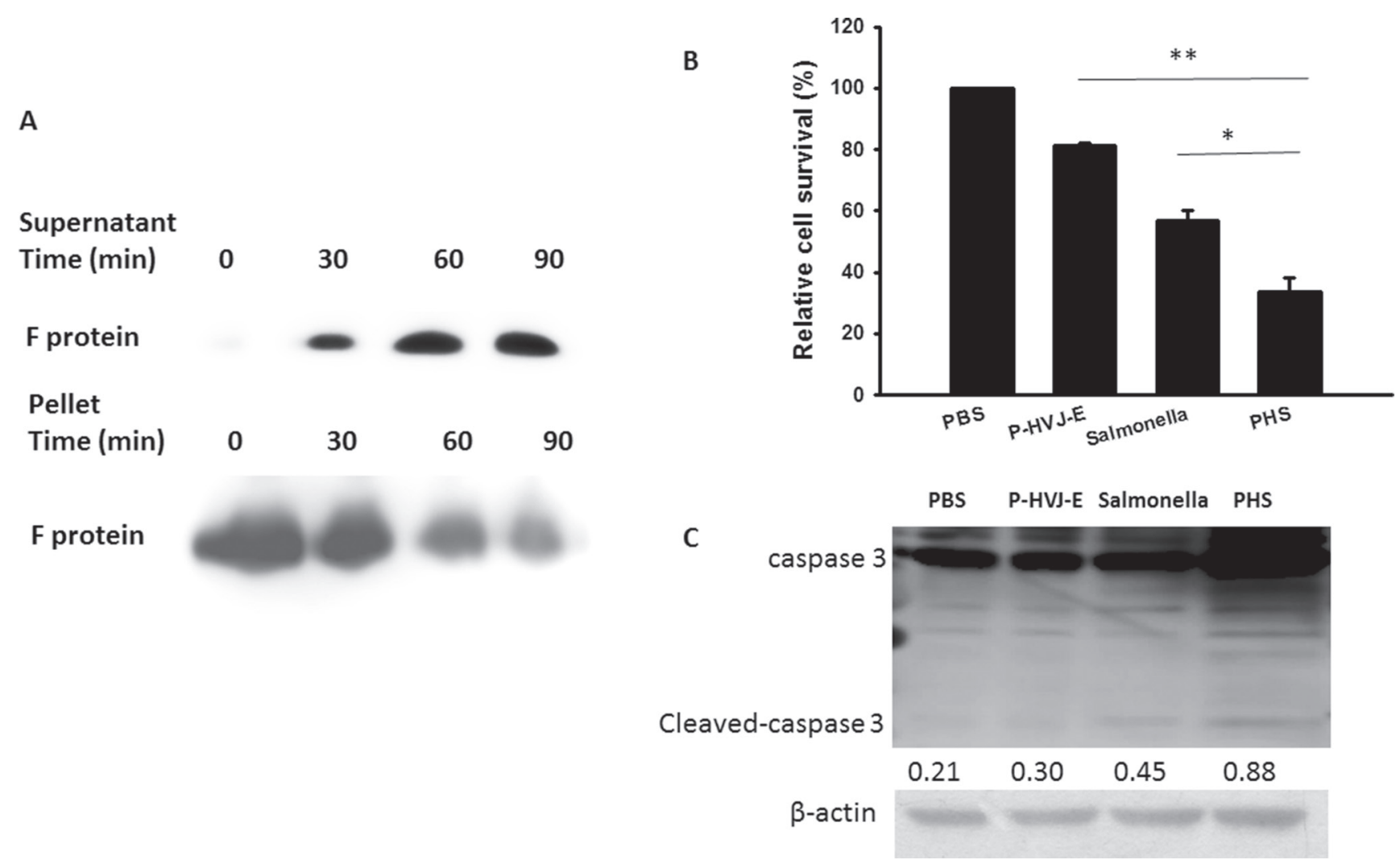

Figure 7: The characterization of PHS. (A) Kinetics of P-HVJ-E release. PAH cells and supernatants were collected at several time points. The F protein of HVJ-E from the solutions was measured by immunoblot analysis. PHS inhibited the proliferation of B16F10 cells. (B) B16F10 cells $\left(10^{5}\right)$ treated with P-HVJ-E (10 HAU), Salmonella $\left(10^{6}\right.$ or PHS $\left(10^{6}\right)$ for $24 \mathrm{~h}$, and the survival rate was then assessed using trypan blue assay. $\left({ }^{*} P<0.05 ;{ }^{*} P<0.01\right)(\mathbf{C})$ B16F10 cells $\left(10^{5}\right)$ treated with P-HVJ-E $\left(10\right.$ HAU), Salmonella $\left(10^{6}\right)$ or PHS $\left(10^{6}\right)$ for $24 \mathrm{~h}$; then, the expression of caspase 3 was assessed using immunoblot assay. The expression of $\beta$-actin served as the quantitative control. Inserted values indicated relative proteins expression in comparison with $\beta$-actin. The cropped blots are displayed. 
tumor. To enhance for this limitation, oncolytic HVJ-E were coating with oppositely charged polymers to adhere to the cell wall of tumor-targeting Salmonella.

The attenuated S. choleraesuis were used for delivery vectors as DNA vaccine [37]. We have demonstrated tumor-targeting and antitumor activities of attenuated S. choleraesuis carrying antiangiogenic genes [23, 38]. S. choleraesuis as single-agent therapy can retards tumor progress and prolong survival in mice bearing lung and liver tumors $[4,39]$. The combination

\section{B16F10}

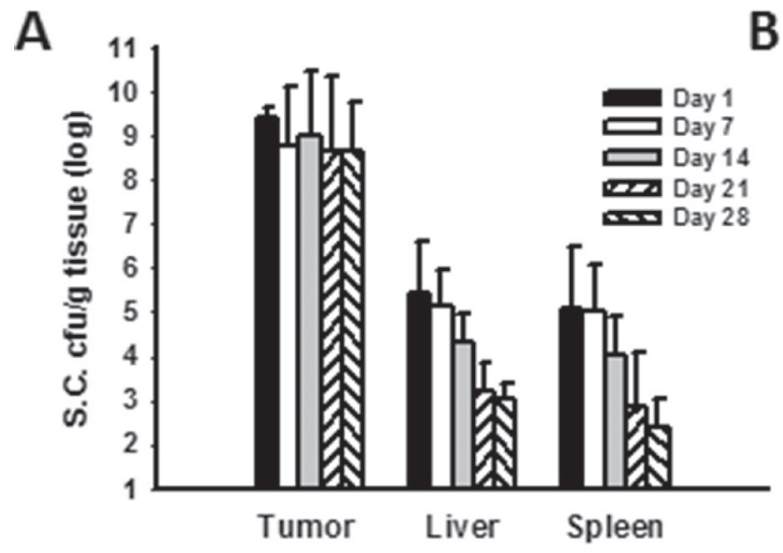

B therapy of S. choleraesuis plus low-dose cisplatin in mice bearing subcutaneous tumors showed the additive antitumor effect [4]. The S. choleraesuis used in our studies were obtained from the S. choleraesuis subsp. choleraesuis serovar Dublin (virulent strain 188) and designated vaccine 51 [40]. We have sequenced the genome of S. choleraesuis. Herein, we extend the tumortargeting function of S. choleraesuis.

HVJ-E has a strong antitumor response after intrtumoral injection, but the hemmagglutination

\section{PC3}

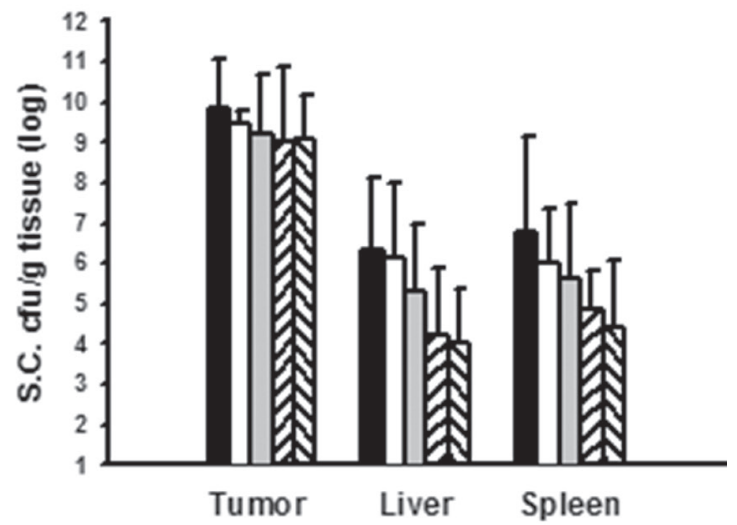

C

$\frac{\text { P-HVJ-E }}{\text { Tumor Liver Spleen Tumor Liver Spleen }}$

B16F10

$F$ protein

$\beta$-actin

F protein

PC3
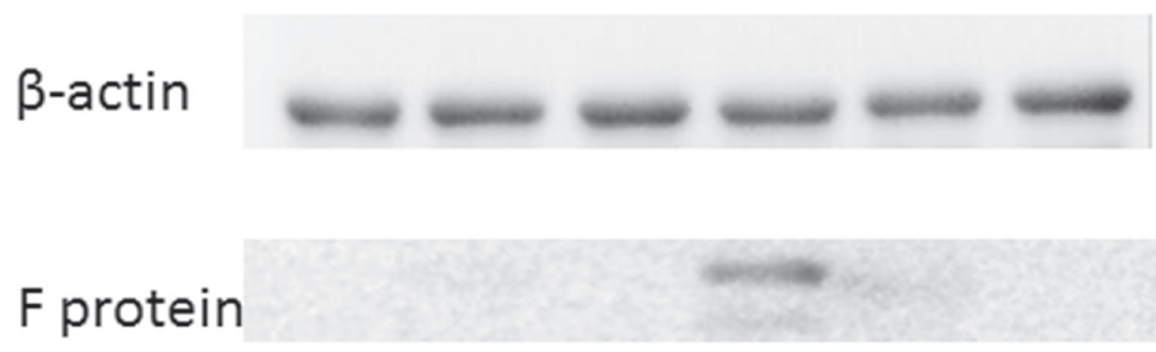

\author{
$\beta$-actin
}

Figure 8: PAH delivered HVJ-E to tumor sites in vivo. The C57BL/6 and SCID mice that had been inoculated subcutaneously with (A) B16F10 $\left(10^{6}\right)$ and (B) PC3 $\left(10^{6}\right)$ at day 0 were treated i.p. with Salmonella $\left(10^{6} \mathrm{CFU} / 100 \mu \mathrm{L}\right)$ at day 8 . Mice bearing tumors ranging from 50-100 $\mathrm{mm}^{3}$ were injected i.p. with PHS $\left(10^{6} \mathrm{cfu}\right)$, and the numbers of Salmonella in the tumors, livers, and spleens were determined at various time points. The data are reported as the means $\pm \mathrm{SD}(n=4-5) ;(\mathbf{C}) \mathrm{B} 16 \mathrm{~F} 10$ and PC3 tumor tissues were lysed and the functional protein of HVJ-E was performed on day 1. This experiment was repeated with similar results. The cropped blots are displayed. 
limit the HVJ-E administration routes. In the present study, HVJ-E that was encapsulated in a biocompatible polymer increased stability in the tissues and reduced the hemmagglutination [30]. We used PAH to produce shells that covered HVJ-E. Coating HVJ-E with such a shell would not inhibit its antitumor ability and function. The fusion protein of HVJ-E may cover with a high concentration of PAH $(1-2 \mu \mathrm{g} / \mathrm{ml})$ and PAH decreased the antitumor activity of HVJ-E. On the contrary, HVJ-E antigenicity was not covered with a low PAH concentration $(0.25 \mu \mathrm{g} / \mathrm{ml})$ and the HVJ-E antigenicity still resulted in hemmagglutination. PHS successfully delivered HVJ-E and inhibited tumor growth. HVJ-E was found in the tumor tissue after PHS systemic administration (Figure 8C). The applications for HVJ-E in cancer therapy will expand by PHS. Recently, a major challenge for cancer therapy is how to induce immune response in tumor microenvironments. Salmonella could not only break tumor immune tolerance, but also accumulate within the tumor region quickly, even leading to tumor cell death. As they have the strong property of activating immunity and killing cancer cells, we believe Salmonella are worth studying and applying to anticancer treatments [21]. HVJ-E does not induce interferon (IFN) $-\gamma$ expression [23]. Previously, we suggested that Salmonella stimulated IFN- $\gamma$ production in T cells and enhanced Th1 immune response through Toll-like receptor 4 signaling [41]. Meanwhile, Salmonella reduced the expression of IDO-1 in tumors, which increased infiltrating immune cells such as macrophages, neutrophils and T cells, within the tumor sites [4]. The HVJ-E has the antitumor activity in various types of cancers. In Japan, clinical trials of the safety and antitumor immunity of HVJ-E are under way [24]. The combination therapy of HVJ-E and other immune modulators, such as Salmonella, exhibits a more effective activation of antitumor immunity. Orthotopic tumor models is very suitable for evaluating the tumortargeting activity of Salmonella [9]. Some studies and our previous results suggested that Salmonella targeted not only in subcutaneous but also in orthotopic tumor models after systemic treatment $[42,43]$.

To investigate the combinatorial effects using Salmonella and oncolytic virus, the Salmonella infection in combination with oncolytic virus was investigated for tumors. Tumor growth was suppressed by this combination therapy, suggesting candidates for oncolytic therapy against tumor growth. This study suggested that Salmonella combined oncolytic virus, augmenting the antitumor activity.
A

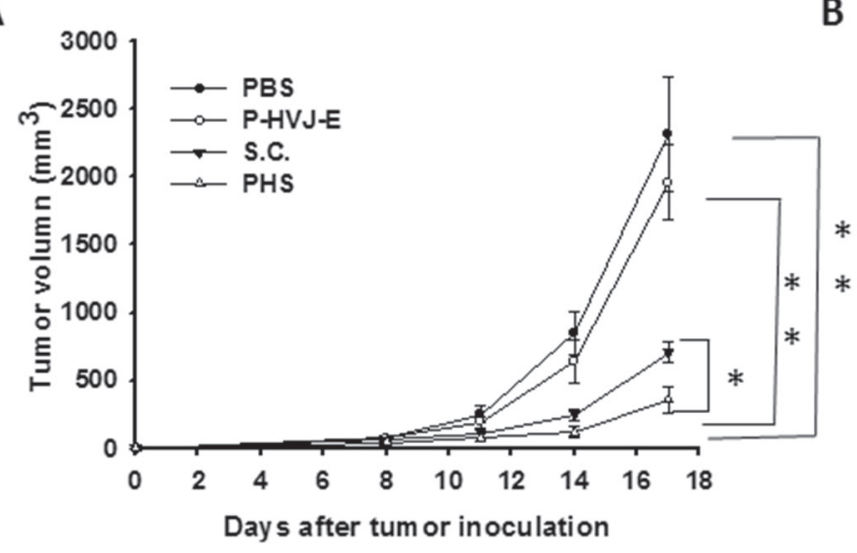

C

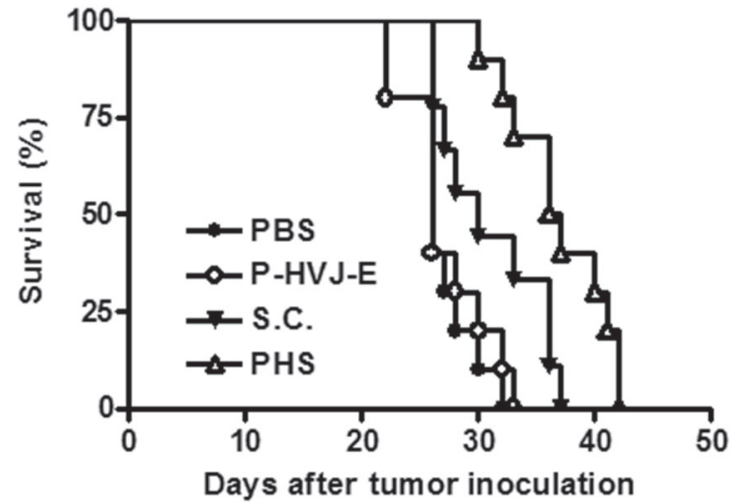

B

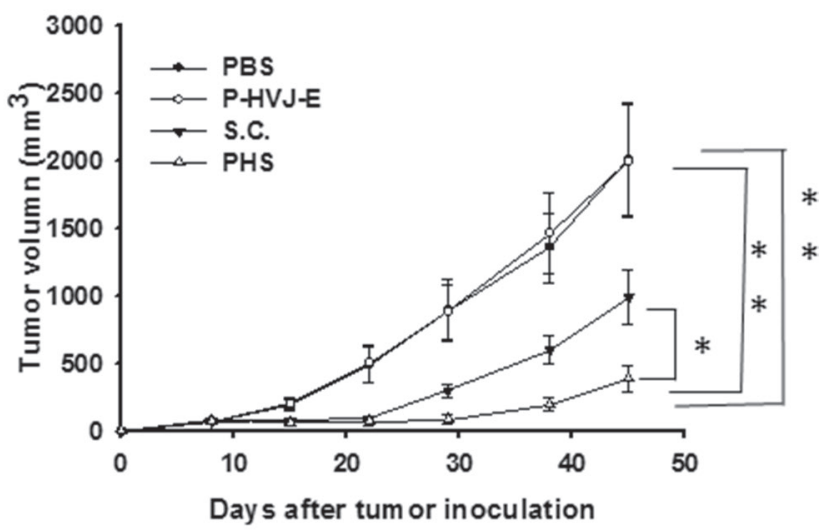

D

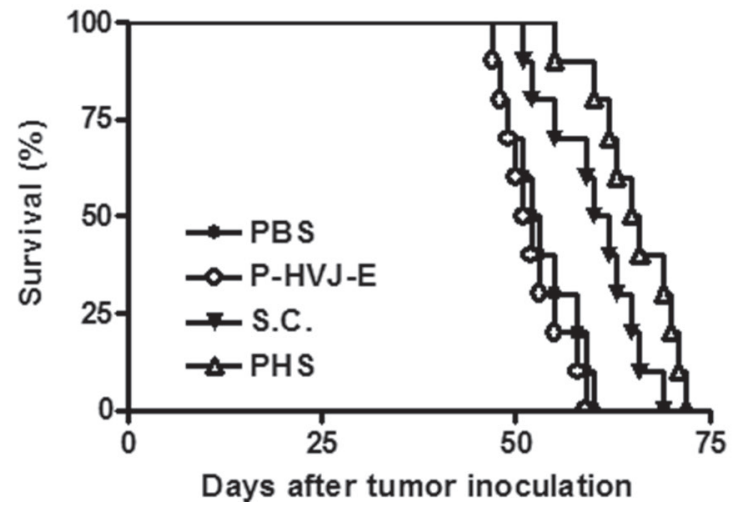

Figure 9: PAH inhibited tumor growth after systemic treatment. The B16F10 (A) and PC3 (B) tumor volumes were measured every 3 days or 7 days after various treatments. This experiment was repeated with similar results. (Salmonella; S.C.) $(n=10$, mean \pm SEM. $* P<0.05 ; * *<0.01)$. Kaplan-Meier survival curves of mice bearing $(\mathbf{C})$ B16F10 and (D) PC3 tumors with different treatments are shown. Data were analyzed by the log-rank test. $(P<0.01$ for PAH versus PBS and HVJ-E; $P<0.05$ for S.C. versus PBS and PHS versus S.C.) 


\section{MATERIALS AND METHODS}

\section{Bacteria, HVJ-E, cells, reagent and mice}

A vaccine strain of S. Choleraesuis [S. choleraesuis subsp. choleraesuis (Smith) Weldin serovar Dublin (ATCC 15480)] was obtained from Bioresources Collection and Research Center (Hsinchu, Taiwan). S. Choleraesuis carried luciferase gene (S.C./Luc) as previous described [26]. HVJ ( $\mathrm{Z}$ strain) was propagated in chicken eggs. The virus was inactivated by UV irradiation $\left(99 \mathrm{~mJ} / \mathrm{cm}^{2}\right)$ immediately prior to each experiment. Viral replication was completely eliminated by UV irradiation. Human PC3 (prostate cancer), PNT2 (prostatic epithelial cells) and B16F10 (melanoma) cells were cultured in Dulbecco's modified Eagle's medium containing $10 \%$ fetal bovine serum, $1 \%$ glutamine, and $50 \mu \mathrm{g} / \mathrm{ml}$ gentamicin at $37^{\circ} \mathrm{C}$ in $5 \% \mathrm{CO} 2$. Mouse bone marrow-derived dendritic cells were collected from mouse tibias and femurs and treated with granulocyte-macrophage colony-stimulating factor (GMCSF) (Sigma-Aldrich, St Louis, MO, USA). Bone marrowderived dendritic cells were ready for experimental use. Polyallylamine hydrochloride ( $\mathrm{PAH}, \mathrm{MW}=15,000$ ), fluorescence-PAH, and PKH26 were purchased from Sigma (Sigma-Aldrich). The HVJ-E was stained with PKH26 according to the manufacturer's instructions and examined under a fluorescence microscope. The levels of cytokines, interleukin-6 (IL-6) in the supernatant of cells after HVJ-E or P-HVJ-E administration was determined by enzyme-linked immunosorbent assay (ELISA) (R \& D, Minneapolis, MN, USA). In the subcutaneous tumor models, mice were injected with $\mathrm{B} 16 \mathrm{~F} 10\left(10^{6}\right)$ or PC3 $\left(10^{6}\right)$ into the left flank. For the evaluation of the tumortargeting potential of Salmonella in tumors, the bacteria present in tumors, blood, liver, and spleen were determined by plating serial dilutions of the homogenates onto LB agar plates, incubating overnight at $37^{\circ} \mathrm{C}$, and counting bacterial colonies. C57BL/6 mice or severe combined immunodeficiency (SCID) mice were purchased from the National Laboratory Animal Center of Taiwan. The animals were maintained in a pathogen-free animal care facility in isothermal conditions with regular photoperiods. The experimental protocol adhered to the rules of the Animal Protection Act of Taiwan and was approved by the Laboratory Animal Care and Use Committee of the China Medical University (permit number: 101-20-N). Groups of $10 \mathrm{C} 57 \mathrm{BL} / 6$ mice or SCID mice were inoculated with B16F10 or PC $3\left(10^{6}\right)$ cells. After 7-9 days, when the tumors were approximately $50-100 \mathrm{~mm}^{3}$, Salmonella $\left(10^{6} \mathrm{cfu}\right)$, P-HVJ-E (100 HAU), PHS ( $\left.10^{6} \mathrm{cfu}\right)$ or PBS was injected intraperitoneally (i.p.) in mice bearing B16F10 or PC3 tumor cells. To analyze tumor volumes, the tumors were measured every 3 days or 1 week in two perpendicular axes using a tissue caliper, and the tumor volumes were calculated as (length of tumor) $\times$ (width of tumor) $)^{2} \times 0.45$. All of the mice were monitored for tumor growth and survival. For the evaluation of the tumor targeting potential of HVJ-E in tumors, the viral particles present in tumors, liver or spleen were determined by immunoblotting assay after 1 day PHS $\left(10^{6} \mathrm{cfu}\right)$ treatment.

\section{Hemagglutination assay}

The hemagglutination assay was performed in a 96-well round-bottom plate using $50 \mu \mathrm{l} /$ well of a $0.5 \%$ suspension of chicken, red blood cells and $50 \mu \mathrm{l} /$ well of a HVJ-E solution serially diluted with PBS.

\section{Gentamicin protection assay, trypan blue assay and luciferase assay}

Cells were infected with Salmonella or PHS after $2 \mathrm{~h}$ incubation; the medium was changed to medium containing $50 \mu \mathrm{g} / \mathrm{ml}$ gentamicin for $1 \mathrm{~h}$. This were followed by two washes with warm PBS and lysis of cells using $0.5 \%(\mathrm{v} / \mathrm{v})$ Triton-X-100/PBS for $20 \mathrm{~min}$ on ice. Serial dilutions were plated on LB agar and incubated overnight at $37^{\circ} \mathrm{C}$; then, the bacterial colonies were counted. Cells $\left(10^{5} /\right.$ well $)$ were infected with $2 \times 10^{6} \mathrm{cfu}$ of Salmonella, PHS or mock-infected with antibioticfree culture medium for $2 \mathrm{~h}$. The medium were removed, washed, and replenished with fresh medium supplemented with $2 \%$ FBS and $50 \mu \mathrm{g} / \mathrm{ml}$ gentamicin. Cell survival was assessed using the trypan blue exclusion assay [44]. Subsequently $10^{6} \mathrm{cfu}$ of S.C./Luc or PHS/Luc were added to these cells which were cultured in $1 \mathrm{ml}$ of antibiotic-free medium and incubated for $8 \mathrm{~h}$. All the cells were washed, replenished with gentamicin $(50 \mu \mathrm{g} /$ $\mathrm{ml}$ )-containing complete medium, and further cultured for $16 \mathrm{~h}$. Cells were ysed to prepare cell extracts for determining luciferase activity by a luciferase assay kit (Tropix, Bedford, MA).

\section{Scanning electron microscope (SEM)}

HVJ-E, P-HVJ-E and PHS were fixed with $2.5 \%$ glutaraldehyde in phosphate buffer and then fixed in $1 \%$ $\mathrm{OsO}_{4}$ solution for $1 \mathrm{~h}$. The samples were dehydrated in a graded ethanol series and embedded in Quetol 812 epoxy resin (Nissin EM, Tokyo, Japan). The samples were examined under a Hitachi electron microscope (Hitachi, Tokyo, Japan).

\section{Western blot analysis}

The protein content in each sample was determined by the bicinchoninic acid (BCA) protein assay (Pierce Biotechnology, Rockford, IL). Then, 60$80 \mu \mathrm{g}$ of protein with $4 \times$ SDS sample dye added was denatured by heating at $10 \mathrm{~min}$ at $95^{\circ} \mathrm{C}$. Proteins were fractionated on SDS-PAGE, transferred onto Hybond enhanced chemiluminescence nitrocellulose membranes (Amersham, Little Chalfont, UK) and detected with 
antibodies against caspase 3 (Cell Signaling, Danvers, MA), caspase 9 (Cell Signaling), Poly (ADP-Ribose) polymerase (PARP) (Cell Signaling), anti-F (fusion protein of HVJ) (Hokkaido System Science Co., Ltd, Hokkaido, Japan) and $\beta$-actin (Sigma Aldrich). Rabbit anti-mouse IgG-peroxidase antibody (Sigma Aldrich) and donkey antirabbit IgG-peroxidase antibody (Sigma Aldrich) were used as the secondary antibody, and protein-antibody complexes were visualized by an enhanced chemiluminescence system (GE Healthcare, UK). The signals were quantified with ImageJ software (rsbweb.nih.gov/ij).

\section{Statistical analysis}

The one-way analysis of variance (one-way ANOVA) was used to determine differences between groups for comparison to the control group. The survival analysis was performed using the Kaplan-Meier survival curve and log-rank test. A $P$ value less than 0.05 was considered to be statistically significant. $\left({ }^{*} P<0.05\right.$; $* * P<0.01 ; * * * P<0.001)$.

\section{Authors' contributions}

C.H. L., T. N., and Y. K. conceived and designed the experiments. C.H. L. performed most of the experiments. T. N. did the SEM. C.H. L., and Y.K. analyzed data. C.H. $\mathrm{L}$ wrote the original manuscript.

\section{ACKNOWLEDGMENTS}

This work was supported by grants from the Ministry of Science and Technology, Taiwan (MOST 104-2320-B-039-042-MY3) and NSYSU-KMU JOINT RESEARCH PROJECT, (\#NSYSUKMU 106-P006).

\section{CONFLICTS OF INTEREST}

The authors have declared that no conflicts of interest exist.

\section{REFERENCES}

1. Park SH, Zheng JH, Nguyen VH, Jiang SN, Kim DY, Szardenings M, Min JH, Hong Y, Choy HE, Min JJ. RGD peptide cell-surface display enhances the targeting and therapeutic efficacy of attenuated Salmonella-mediated cancer therapy. Theranostics. 2016; 6:1672-1682.

2. Chang WW, Lee CH. Salmonella as an innovative therapeutic antitumor agent. Int J Mol Sci. 2014; 15:14546-14554.

3. Forbes NS. Engineering the perfect (bacterial) cancer therapy. Nat Rev Cancer. 2010; 10:785-794.

4. Lee CH, Wu CL, Tai YS, Shiau AL. Systemic administration of attenuated Salmonella choleraesuis in combination with cisplatin for cancer therapy. Mol Ther. 2005; 11:707-716.
5. Pawelek JM, Low KB, Bermudes D. Tumor-targeted Salmonella as a novel anticancer vector. Cancer Res. 1997; 57:4537-4544.

6. Zhao M, Yang M, Li XM, Jiang P, Baranov E, Li S, Xu M, Penman S, Hoffman RM. Tumor-targeting bacterial therapy with amino acid auxotrophs of GFP-expressing Salmonella typhimurium. Proceedings of the National Academy of Sciences of the United States of America.. 2005; 102:755-760.

7. Hiroshima Y, Zhang Y, Zhao M, Zhang N, Murakami T, Maawy A, Mii S, Uehara F, Yamamoto M, Miwa S, Yano S, Momiyama M, Mori R, et al. Tumor-Targeting Salmonella typhimurium A1-R in combination with trastuzumab eradicates HER-2-positive cervical cancer cells in patientderived mouse models. PloS One. 2015; 10: e0120358.

8. Matsumoto Y, Miwa S, Zhang Y, Zhao M, Yano S, Uehara F, Yamamoto M, Hiroshima Y, Toneri M, Bouvet M, Matsubara H, Tsuchiya H, Hoffman RM. Intraperitoneal administration of tumor-targeting Salmonella typhimurium A1-R inhibits disseminated human ovarian cancer and extends survival in nude mice. Oncotarget. 2015; 6:11369-11377. doi: 10.18632/oncotarget.3607.

9. Miwa S, Zhang $\mathrm{Y}$, Baek KE, Uehara F, Yano S, Yamamoto M, Hiroshima Y, Matsumoto Y, Kimura H, Hayashi K, Yamamoto N, Bouvet M, Tsuchiya H, et al. Inhibition of spontaneous and experimental lung metastasis of soft-tissue sarcoma by tumor-targeting Salmonella typhimurium A1-R. Oncotarget. 2014; 5:12849-12861. doi: 10.18632/oncotarget.2561.

10. Zhang Y, Miwa S, Zhang N, Hoffman RM, Zhao M. Tumortargeting Salmonella typhimurium A1-R arrests growth of breast-cancer brain metastasis. Oncotarget. 2015; 6:2615-2622. doi: 10.18632/oncotarget.2811.

11. Hayashi K, Zhao M, Yamauchi K, Yamamoto N, Tsuchiya H, Tomita K, Hoffman RM. Cancer metastasis directly eradicated by targeted therapy with a modified Salmonella typhimurium. J Cell Biochem. 2009; 106:992-998.

12. Hiroshima Y, Zhang Y, Murakami T, Maawy A, Miwa S, Yamamoto M, Yano S, Sato S, Momiyama M, Mori R, Matsuyama R, Chishima T, Tanaka K, et al. Efficacy of tumor-targeting Salmonella typhimurium A1-R in combination with anti-angiogenesis therapy on a pancreatic cancer patient-derived orthotopic xenograft (PDOX) and cell line mouse models. Oncotarget. 2014; 5:12346-12357. doi: 10.18632/oncotarget.2641.

13. Hiroshima Y, Zhao M, Maawy A, Zhang Y, Katz MH, Fleming JB, Uehara F, Miwa S, Yano S, Momiyama M, Suetsugu A, Chishima T, Tanaka K, et al. Efficacy of Salmonella typhimurium A1-R versus chemotherapy on a pancreatic cancer patient-derived orthotopic xenograft (PDOX). J Cell Biochem. 2014; 115:1254-1261.

14. Hiroshima Y, Zhao M, Zhang Y, Maawy A, Hassanein MK, Uehara F, Miwa S, Yano S, Momiyama M, Suetsugu A, Chishima T, Tanaka K, Bouvet M, et al. Comparison of efficacy of Salmonella typhimurium A1-R and chemotherapy on stem-like and non-stem human pancreatic cancer cells. Cell Cycle. 2013; 12:2774-2780. 
15. Kimura H, Zhang L, Zhao M, Hayashi K, Tsuchiya H, Tomita K, Bouvet M, Wessels J, Hoffman RM. Targeted therapy of spinal cord glioma with a genetically modified Salmonella typhimurium. Cell Prolif. 2010; $43: 41-48$.

16. Yam C, Zhao M, Hayashi K, Ma H, Kishimoto H, McElroy M, Bouvet M, Hoffman RM. Monotherapy with a tumor-targeting mutant of S. typhimurium inhibits liver metastasis in a mouse model of pancreatic cancer. J Surg Res. 2010; 164:248-255.

17. Yano S, Zhang Y, Zhao M, Hiroshima Y, Miwa S, Uehara F, Kishimoto H, Tazawa H, Bouvet M, Fujiwara T, Hoffman RM. Tumor-targeting Salmonella typhimurium A1-R decoys quiescent cancer cells to cycle as visualized by FUCCI imaging and become sensitive to chemotherapy. Cell Cycle. 2014; 13:3958-3963.

18. Zhao M, Geller J, Ma H, Yang M, Penman S, Hoffman RM. Monotherapy with a tumor-targeting mutant of Salmonella typhimurium cures orthotopic metastatic mouse models of human prostate cancer. Proceedings of the National Academy of Sciences of the United States of America. 2007; 104:10170-10174.

19. Zhao M, Yang M, Ma H, Li X, Tan X, Li S, Yang Z, Hoffman RM. Targeted therapy with a Salmonella typhimurium leucine-arginine auxotroph cures orthotopic human breast tumors in nude mice. Cancer Res. 2006; 66:7647-7652.

20. Kim JE, Phan TX, Nguyen VH, Dinh-Vu HV, Zheng JH, Yun M, Park SG, Hong Y, Choy HE, Szardenings M, Hwang W, Park JA, Park S, et al. Salmonella typhimurium suppresses tumor growth via the pro-inflammatory cytokine Interleukin-1 $\beta$. Theranostics. 2015; 5:1328-1342.

21. Kuan YD, Lee CH. Salmonella overcomes tumor immune tolerance by inhibition of tumor indoleamine 2, 3-dioxygenase 1 expression. Oncotarget. 2016; 7:374-385. doi: 10.18632/oncotarget.6258.

22. Tu DG, Chang WW, Lin ST, Kuo CY, Tsao YT, Lee CH. Salmonella inhibits tumor angiogenesis by downregulation of vascular endothelial growth factor. Oncotarget. 2016; 7:37513-3752. doi: 10.18632/oncotarget.7038.

23. Lee $\mathrm{CH}, \mathrm{Wu} \mathrm{CL}$, Shiau AL. Endostatin gene therapy delivered by Salmonella choleraesuis in murine tumor models. J Gene Med. 2004; 6:1382-1393.

24. Saga K, Kaneda Y. Virosome presents multimodel cancer therapy without viral replication. Biomed Res Int 2013; 2013: 764706.

25. Saga K, Kaneda Y. Oncolytic Sendai virus-based virotherapy for cancer: recent advances. Oncolytic Virother. 2015; 4:141-147.

26. Lee $\mathrm{CH}$, Lin $\mathrm{YH}$, Hsieh JL, Chen MC, Kuo WL. A polymer coating applied to Salmonella prevents the binding of Salmonella-specific antibodies. Int J Cancer. 2013; 132:717-725.

27. Jiang Y, Saga K, Miyamoto Y, Kaneda Y. Cytoplasmic calcium increase via fusion with inactivated Sendai virus induces apoptosis in human multiple myeloma cells by downregulation of c-Myc oncogene. Oncotarget. 2016; 7:36034-36048. doi: 10.18632/oncotarget.9105.

28. Mima H, Yamamoto S, Ito M, Tomoshige R, Tabata Y, Tamai K, Kaneda Y. Targeted chemotherapy against intraperitoneally disseminated colon carcinoma using a cationized gelatin-conjugated HVJ envelope vector. Mol Cancer Ther. 2006; 5:1021-1028.

29. Nishikawa T, Tung LY, Kaneda Y. Systemic administration of platelets incorporating inactivated Sendai virus eradicates melanoma in mice. Mol Ther. 2014; 22:2046-2055.

30. Mima H, Tomoshige R, Kanamori T, Tabata Y, Yamamoto S, Ito S, Tamai K, Kaneda Y. Biocompatible polymer enhances the in vitro and in vivo transfection efficiency of $\mathrm{HVJ}$ envelope vector. J Gene Med. 2005; 7:888-897.

31. Suzuki H, Kurooka M, Hiroaki Y, Fujiyoshi Y, Kaneda Y. Sendai virus F glycoprotein induces IL-6 production in dendritic cells in a fusion-independent manner. FEBS Lett. 2008; 582:1325-1329.

32. Kurooka M and Kaneda Y. Inactivated Sendai virus particles eradicate tumors by inducing immune responses through blocking regulatory T cells. Cancer Res. 2007; 67:227-236.

33. Chang WW, Lai CH, Chen MC, Liu CF, Kuan YD, Lin ST, Lee CH. Salmonella enhance chemosensitivity in tumor through connexin 43 upregulation. Int J Cancer. 2013; 133:1926-1935.

34. Wang WK, Lu MF, Kuan YD, Lee CH. The treatment of mouse colorectal cancer by oral delivery tumor-targeting Salmonella. Am J Cancer Res. 2015; 5:2222-2228.

35. Wang WK, Kuan YD, Kuo CY, Lee CH. Connexin 43 gene therapy delivered by polymer-modified Salmonella in murine tumor models. Polymers. 2014; 6:1119-1128.

36. Chang WW, Kuan YD, Chen MC, Lin ST, Lee CH. Tracking of mouse breast cancer stem-like cells with Salmonella. Exp Biol Med. 2012; 237:1189-1196.

37. Shiau AL, Chen YL, Liao CY, Huang YS, Wu CL. Prothymosinaenhances protective immune responses induced by oral DNA vaccination against pseudorabies delivered by Salmonella choleraesuis. Vaccine 2001; 19 : 3947-3956.

38. Lee, $\mathrm{CH}, \mathrm{Wu} \mathrm{CL}$, Shiau AL. Systemic administration of attenuated Salmonella choleraesuis carrying thrombospondin-1 gene leads to tumor-specific transgene expression, delayed tumor growth and prolonged survival in the murine melanoma model. Cancer Gene Ther. 2005; 12:175-184.

39. Lee $\mathrm{CH}, \mathrm{Wu} \mathrm{CL}$, Shiau AL. Salmonella choleraesuis as an anticancer agent in a syngeneic model of orthotopic hepatocellular carcinoma. Int J Cancer. 2008; 122:930-935.

40. Smith HW. The immunization of mice, calves and pigs against Salmonella dublin and Salmonella choleraesuis infections. J Hyg (Lond). 1965; 63:117-135.

41. Lee CH, Wu CL, Shiau AL. Toll-like receptor 4 mediates an antitumor host response induced by Salmonella choleraesuis. Clin Cancer Res. 2008; 14:1905-1912. 
42. Hoffman RM. Orthotopic metastatic mouse models for anticancer drug discovery and evaluation: a bridge to the clinic. Invest. New Drugs. 1999; 17:343-349.

43. Hoffman RM. Patient-derived orthotopic xenografts: better mimic of metastasis than subcutaneous xenografts. Nat Rev Cancer. 2015; 15:451-452.
44. Lee CH, Lin ST, Liu JJ, Chang WW, Hsieh JL, Wang WK. Salmonella induce autophagy in melanoma by the downregulation of AKT/mTOR pathway. Gene Ther. 2014; 21:309-316. 